\title{
Performance Evaluation of Implementation of Regional Special-Purpose Programs
}

\author{
Novenkova A. Z. ${ }^{1}$, Feifer-Shishkina R. L. ${ }^{1}$ \& Khovanskaya E. S. ${ }^{1}$ \\ ${ }^{1}$ Kazan Federal University, Institute of Management, Economics and Finance, Kazan, Russia \\ Correspondence: Novenkova A. Z., Kazan Federal University, Institute of Management, Economics and Finance, \\ Kazan, 420008, Russia.
}

Received: March 10, 2015 Accepted: March 31, 2015 Online Published: April 30, 2015

doi:10.5539/ass.v11n11p233 URL: http://dx.doi.org/10.5539/ass.v11n11p233

\begin{abstract}
The article analyses the algorithm of development and implementation of regional special-purpose programs on the example of the special-purpose program "Rural Youth of the Republic of Tatarstan for 2011-2015"; the assessment of the program using performance indicators that include the level of execution of the planned funding is conducted; the level of achievement of the performance indicator; the effectiveness of budget spending; the effective implementation of the long-term program in the reporting under report.
\end{abstract}

Keywords: regional special-purpose program, Management by Objectives method of the regional development planning, performance indicators of implementation of regional programs, of resources provision of regional programs, budgeting

\section{Introduction}

Growing interest to the regional economy in recent years is caused by real changes in the system of social relations reflected on separation of rights and responsibilities of the federal center and the subject entities of the Federation. The growing financial dependence of the regions from the success of business operating in the region makes regional authorities look for effective organizational and economic technologies in building the relationships with economic entities that facilitate the development and implementation of the long-term social and economic policy. Changes in the content of the budget process resulted in the radical restructuring of the development of regional budgets. The transition from the cost-based principle to the program-oriented principle of budgeting made drastic changes in the system of management of the regional development, and the special regional purpose-oriented programs became the basis of it. Numerous works of the Russian (Akhtyamova, Bagautdinova, \& Novenkova, 2013; Bagautdinova, Gafurov, \& Novenkova, 2013; Bagautdinova, Gafurov, Kalenskaya, \& Novenkova, 2012) and foreign authors (Bagautdinova, Panasyuk, \& Gafurov, 2013; Howarth \& Norgard, 1992, May; Ohmae, 1995; Friedmann \& Alonso, 1978; Richardson, 1973; Townroe, 1979) are devoted to the problems of regional development. However, the introduction of tools of the Management by Objectives planning results in the necessity to develop performance evaluation indicators adapted to characteristics of some regional entities. All this determines the relevance of the research topic, its theoretical and practical significance.

\section{Methodology}

Integration of objectives with resources through the development of programs is a peculiarity of the program-oriented approach. This method of budgeting is based on the scheme "goals-ways-methods-means." Development and implementation of special-purpose programs became an effective way of solution of major problems that involves the concentration of resources, focus of efforts, target orientation of the means, coordination of actions.

Advantages and disadvantages of the Management by Objectives method are presented in the Table 1 (Allen \& Tommasi, 2001).

The mechanism of formation of purpose-oriented programs starts with the selection and justification of the problem to be solved, determination of estimated figures, selection of the period of time, of resource provision and forms of financing. In general, the algorithm of development and approval of the purpose-oriented program consists of selection of a program object, derivation of the tree of objectives, foundation of planned activities, structuring of the program by time, performers and subprograms, resource assessment, marketing research, 
formation of organizational structures, control of operations. National programs are one of the important means of implementation of the structural policy of the Republic of Tatarstan, the active influence on its socio-economic development and should focus on implementation of the large-scale - the most important for the republic - investment and R \& D projects aimed at solution of systemic problems within the competence of executive authorities of the Republic of Tatarstan.

Table 1. Advantages and disadvantages of the management by objectives method

\begin{tabular}{ll}
\hline Existing problems & Objectives of introduction of the program-oriented method \\
\hline Weak cost-benefit links & Results-oriented budget planning activities of the entity \\
$\begin{array}{l}\text { Insufficiently effective level of financial planning } \\
\text { and financial control }\end{array}$ & Higher level of financial planning and financial control \\
Inefficient use of budgetary funds & $\begin{array}{l}\text { Control of the intended use of budgetary funds } \\
\text { Optimization of budgetary expenditures }\end{array}$ \\
\hline
\end{tabular}

Socio-economic development of the republic in various fields (education, health service, communications, transportation, etc.), modernization of the lifestyle in rural areas and increase of their attractiveness as a result of promising activities will allow to create optimal opportunities for the rural youth who want to live in rural area. Evaluation of the long-term program effectiveness is carried out by the results of its implementation for the financial year and for the entire period of the program as a whole on the basis of the reports presented by the entity of budget planning in the prescribed form. Performance evaluation of the implementation is carried out using the following indicators:

1. The level of execution of the planned funding $(C)$;

2 .The level of achievement of the performance indicator (I);

3. Value for budgetary money $(\mathrm{R})$;

4. Effectiveness of implementation of the long-term program in the reporting period (E);

5. Effectiveness of the long-term special-purpose program for the entire period of implementation (E).

The following types of performance indicators are used to calculate the level of achievement of the performance indicator (I): direct (increase of the index value is positive dynamics); reverse (reduction of the indicator value is positive dynamics). Effectiveness evaluation of the long-term special-purpose program is carried out for every activity (group of actions), in respect of which the amount of funding and the corresponding performance indicator(s) is determined.

Calculation of the indicator $\mathrm{R}$ by the corresponding activities (set of activities) is made by the formula:

$$
\mathrm{R}=\mathrm{I} / \mathrm{C} \times 100 \% \text {, where }
$$

I - the level of achievement of performance indicators that characterizes the execution of the activities (set of activities);

$\mathrm{C}$ - the level of execution of the planned funding for the execution of the activities (set of activities).

Calculation of the indicator I by the corresponding activities (set of activities) is made by the formula:

a) for the direct performance indicator: $\quad I=I F / I P \times 100 \%$

b) for the reversed performance indicator: $\quad I=I P / I F x ~ 100 \%$, where

IF - the actual value of the performance indicator that characterizes the implementation of activities (set of activities);

IP - the planned (improved) value of the performance indicator that characterizes the implementation of activities (set of activities).

If the activities (set of activities) are characterized by several performance indicators, then the arithmetical mean of the level of achievement of all relevant indicators is used in the calculation of $\mathrm{R}$.

Calculation of the indicator $\mathrm{C}$ by the corresponding activities (set of activities) is made by the formula:

$$
\mathrm{C}=\mathrm{CF} / \mathrm{CP} \times 100 \% \text {, where }
$$


$\mathrm{CF}$ - the actual budgetary allocations aimed at implementation of activities (set of activities);

$\mathrm{CP}$ - the planned (improved) budgetary allocations aimed at implementation of activities (set of activities).

Funding allocation for each activity of the set of activities is defined for the set of activities the implementation of which is characterized by one performance indicator; calculation of the indicator $\mathrm{C}$ made on the basis of comparison of the total amount of funding for the set of activities (the ratio of implementation of the planned amount of funding of the improved amount of funding). Value of the efficiency indicator of budget spending in the reporting period R should not exceed $200 \%$.

\section{Results}

Arrangement of conditions for the activity increase of the social and economic activities of the rural youth of the Republic of Tatarstan is the aim of the regional program "Rural youth of the Republic of Tatarstan for 2011-2015". The budget means of the Republic of Tatarstan are employed for implementation of the Program measures based on the capabilities of the budget of the Republic of Tatarstan, and the employment of funds of municipalities and extra-budgetary sources is assumed. With the account of possibilities of the budget of the Republic of Tatarstan, local budgets and extra-budgetary funds the amount of funds allocated for the implementation of the Program are specified every year during the development of the budget of the Republic of Tatarstan during the period of the program.

Evaluation of budget effectiveness of the special-purpose program is based on an analysis of the following indicators (Tables $2,3,4,5,6$ ).

Table 2. The share of youth of the republic at the age from 14 to 30 who are aware of the program implementation, in the total number of young people, $\%$

\begin{tabular}{cccccc}
\hline 2011 & 2012 & 2013 & 2014 & 2015 & 2016 \\
\hline 0 & 30 & 38,8 & 48,7 & 58,6 & 68,5 \\
\hline
\end{tabular}

Table 3. The share of youth of the republic at the age from 14 to 30 who are involved in the activities of the Program (by the cumulative total), number of people

\begin{tabular}{cccccc}
\hline 2011 & 2012 & 2013 & 2014 & 2015 & 2016 \\
\hline 0 & 15000 & 30000 & 45000 & 60000 & 75000 \\
\hline
\end{tabular}

Table 4. Year-on-year increase for $5 \%$ of the number of youth of the republic at the age from 14 to 30 who consider the business activities as the strategy of their own development, number of people

\begin{tabular}{cccccc}
\hline 2011 & 2012 & 2013 & 2014 & 2015 & 2016 \\
\hline 20476 & 21500 & 22575 & 23703 & 24888 & 26133 \\
\hline
\end{tabular}

Table 5. Number of participants of the Program who developed the business projects during its implementation (by the cumulative total), number of people

\begin{tabular}{cccccc}
\hline 2011 & 2012 & 2013 & 2014 & 2015 & 2016 \\
\hline 0 & 700 & 1400 & 2200 & 3000 & 4200 \\
\hline
\end{tabular}

Table 6. Number of participants of the Program who organized their own business enterprises during its implementation (by the cumulative total), number of enterprises.

\begin{tabular}{cccccc}
\hline 2011 & 2012 & 2013 & 2014 & 2015 & 2016 \\
\hline 0 & 250 & 500 & 750 & 1000 & 1250 \\
\hline
\end{tabular}

These indicators are planned. They are reflected in the program passport and are calculated on the basis of statistical data of Federal Service of State Statistics of the Republic of Tatarstan (Ministry of Economics of the Republic of Tatarstan). 
Effectiveness of the Program implementation and of the use of the allocated for it budget means of the Russian Federation, the Republic of Tatarstan and extra-budgetary funds will be provided through the following: elimination of possibility of improper use of budget funds; "transparency" of the use of budget funds; target specific provision of budget funds. Successful implementation of the Program activities will allow to ensure: development of human resources potential; interest of young people in the socio-economic development and their willingness to participate in this process; to create new small and medium-sized businesses; to create new work places; to increase the margin of innovative enterprises; to increase tax revenues; to reduce social tension among young people; to increase the level of public confidence to government institutions; to improve the quality of life of population.

We will calculate the indicator C for the program "Rural youth". According to reports of the Ministry of Youth, Sports and Tourism of the Republic of Tatarstan, the indicators of the actually used funding by the program (CF) are the following:

$2011-0$ rubles;

2012- 4 438,2 rubles;

2013- 4 438,2 rubles.

Planned indicators (CP) were the following:

$2011-4$ 438,2 rubles;

2012 - 4 438,2 rubles;

$2013-4$ 438,2 rubles.

Thus, the level of implementation of the planned amount of funding by years is the following:

$2011-\mathrm{C}=0 / 4$ 438,2 rubles * $100 \%=0 \%$

$2012-\mathrm{C}=4$ 438,2 rubles $/ 4438,2$ rubles $* 100 \%=100 \%$

$2013-\mathrm{C}=4$ 438,2 rubles $/ 4438,2$ rubles $* 100 \%=100 \%$

The level of achievement of the performance indicator (I) and the efficiency of budget spending (R) for each of the program indicators were calculated using data of 2012 and 2013, since in 2011 the program was not funded.

1. The planned share of youth of the republic at the age from 14 to 30 who are aware of the program implementation, in the total number of young people (IF): $2012-30 \%, 2013-38,8 \%$. Actual data, \%, (IF): 2012 - 28\%, $2013-39,04 \%$. Thus: the level of achievement of the performance indicator (I) is the following:

$2012-\mathrm{I}=28 / 30 * 100 \%=93,3 \%$

$2013-\mathrm{I}=39,04 / 38,8 * 100 \%=100,6 \%$

The effectiveness of budget spending $(\mathrm{R})$ is:

$2012-\mathrm{R}=93,3 \%$

$2013-\mathrm{R}=100,6 \%$

2. The planned number of young people of the republic at the age from 14 to 30 who are involved in the activities of the Program (by the cumulative total), number of people (IP): 2012 - 15000 people, 2013 - 30000 people. Actual data IF: $2012-12300$ people, $2013-26430$ people.

Thus, the level of achievement of the performance indicator (I) is:

$2012-\mathrm{I}=12300 / 15000 * 100 \%=82 \%$

$2013-\mathrm{I}=26430 / 30000 * 100 \%=88,1 \%$

The effectiveness of budget spending $(\mathrm{R})$ is:

$2012-\mathrm{R}=82 \%$

$2013-\mathrm{R}=88,1 \%$

3. Planned year-on-year increase for $5 \%$ of the number of youth of the republic at the age from 14 to 30 who consider the business activities as the strategy of their own development, number of people (IP): $2013-22575$ people, $2014-23703$ people. Actual data of IF: 2013 - 20000 people, $2014-21000$ people.

Thus, the level of achievement of the performance indicator (I) is:

$2012-\mathrm{I}=20000 / 22575 * 100 \%=88,9 \%$ 
$2013-\mathrm{I}=21000 / 23703 * 100 \%=88,5 \%$

The effectiveness of budget spending $(\mathrm{R})$ is:

$2012-\mathrm{R}=88,9 \%$

$2013-\mathrm{R}=88,5 \%$

4. Planned number of participants of the Program who developed the business projects during its implementation (by the cumulative total), number of people (IP): 2012 - 700 people, 2013 - 1400 people. Actual data of IF: $2012-700$ people, $2013-1400$ people. By this index all indicators are $100 \%$.

5. Planned number of the Program participants who organized their own business enterprises during its implementation (by the cumulative total), number (IP): 2012 - 250, 2013 - 500. Actual data of IF: $2012-250$, $2013-500$. By this index all indicators are $100 \%$.

Calculation of the effective implementation of the long-term program in the reporting period (E) is carried out by calculating the arithmetic mean from all particular values of the indicator $\mathrm{R}$ for every activity (set of activities). Calculation of the effective implementation of the long-term specific-oriented program for the entire period of implementation (E) is carried out by calculating the arithmetic mean from the values of the indicator $\mathrm{E}$ for every year of the program.

Upon completion of the calculation of indicators the conclusions of the evaluation of effectiveness of the long-term program implementation - taking into account the following criteria - are formulated:

- Indicator value (E) is from $90 \%$ to $110 \%$ : the implementation of the program corresponds to the planned results with the planned total amount of expenditures (planned efficiency of the program);

- Indicator value (E) is more than $110 \%$ : the performance efficiency of the program is higher than the planned one;

- Indicator value (E) is from $50 \%$ to $90 \%$ : the performance efficiency of the program is lower than the planned one;

- Indicator value (E) is less than $50 \%$ : the program is implemented inefficiently.

By the results of evaluation the decision concerning effectiveness of the long-term program implementation is formed - on the wording of one of the conclusions:

1. Performance efficiency of the program decreased in comparison with the initially planned one.

2. Performance efficiency of the program is on the same level as the planned one.

3. Performance efficiency of the program increased in comparison with the initially planned one.

4. The program is implemented inefficiently.

Decrease or increase of effectiveness of the Program implementation is the basis for possible reduction of funds allocated to the subject of budget planning in the next financial year for the implementation of the Program.

Conclusion concerning ineffectiveness of implementation of the long-term special program is the basis for possible early termination of its implementation.

Accordingly, on the basis of the available data we will calculate indicators for the program "Rural youth".

2012: $\mathrm{E}=(88,9 \%+93,3 \%+82 \%+100 \%+100 \%) / 5=92,84 \%$

2013: $\mathrm{E}=(100,6 \%+88,1 \%+88,5 \%+100 \%+100 \%) / 5=95,44 \%$

Based on the available results we can conclude that implementation of the long-term purpose-oriented program "Rural Youth for 2011-2015" corresponds to the planned results with the planned amount of expenditures.

\section{Statements}

The analysis showed that the following activities - concerning modernization of the program-oriented approach - also contributes to the efficiency improvement of the development and implementation of regional special programs.

1) Re-orientation of budgetary expenditures for "management of results", the project approach for every purpose-oriented program. Currently the blur of goals and objectives, incorrect character of their statement is typical for a large number of the existing regional programs, and this makes them unverifiable in some cases, and unattainable - in other cases. 
2) Integration into the system of management of the program of independent expert procedures. Possibilities of improvement of the system of management of the regional economy development program, of identification of its problems, of assurance of assessment objectivity and increase of public confidence to the program-oriented methods are largely determined by the procedures of the independent expertise within the frames of management of program implementation.

3) Organization of monitoring of the program implementation and its incorporation into the decision-making process. An effective system of monitoring of its implementation is a prerequisite of the effective management of the special program of regional economic development. However, mechanisms of monitoring of the regional economy development programs are, as a rule, not clearly defined: there are no requirements to periodicity to hold them, to the composition of collected data and to processes of their acquisition.

4) Creation of a new managerial body of special programs which is responsible for monitoring, qualitative assessment of special programs effectiveness, analysis of reasons of failure and factors of successful execution of program special indicators, development of applied recommendations to prevent and restore deviations of program special indicators, to identify factors of efficient implementation.

5) Strengthening of personal responsibility for the results of the program.

6) Formation and approval of transition trends from short-term and medium-term to long-term development plans and programs of the region; formation of the unified methodology of development of regional plans taking into account the territory development strategy.

7) Implementation of the fundraising system to attract more extra-budgetary funding of projects.

\section{References}

Akhtyamova, N. M., Bagautdinova, N. G., \& Novenkova, A. Z. (2013). Conceptual Features of Management Models in the West and East. World Applied Sciences Journal, 27(13), 10-14.

Allen, R., \& Tommasi, D. (2001). Published Managing Public Expenditure A Reference Book for Transition Countries (p. 504). OECD Publishing.

Bagautdinova, N. G., Gafurov, I. R., \& Novenkova, A. Z. (2013). The transformation of region's economic area governed by the development of industrial region. World Applied Sciences Journal, 25(7), 1113-1117.

Bagautdinova, N. G., Panasyuk, M. V., \& Gafurov, I. R. (2013). Wavelet analysis of the territorial socio-economic system dynamics. World Applied Sciences Journal, 27(13), 62-66.

Bagautdinova, N., Gafurov, I., Kalenskaya, N., \& Novenkova, A. (2012). The regional development strategy based on territorial marketing (The Case of Russia). World Applied Sciences Journal, 18(18), 179-184.

Friedmann, J., \& Alonso, W. (Eds.). (1978). Regional policy: Readings in Theory and Applications. MIT Press, England.

Howarth, R. B., \& Norgard, R. B. (1992, May). Environmental Valuation under Sustainable Development. American Economic Review, 82(2). Papers and Proceedings of the Hundred and Fourth Annual Meeting of the American Economic Association.

Official site of the Ministry of Economics of the Republic of Tatarstan. Retrieved from http://mert.tatarstan.ru

Ohmae, K. (1995). The End of the Nation State: The Rise of Regional Economics. N.Y.

Richardson, H. W. (1973). Regional growth theory. London: MacMillan.

Townroe, P. M. (1979). Location factors in the decentralization of industry: A survey of Metropolitan. Sao Paulo, Brazil, World Bank Staff Working Paper, 517.

\section{Copyrights}

Copyright for this article is retained by the author(s), with first publication rights granted to the journal.

This is an open-access article distributed under the terms and conditions of the Creative Commons Attribution license (http://creativecommons.org/licenses/by/3.0/). 